\title{
NEW-BUILD GENTRIFICATION \\ IN THE POST-SOCIALIST CITY: ŁÓDŹ AND LEIPZIG TWO DECADES AFTER SOCIALISM
}

\begin{abstract}
HOLM, A., MARCIŃCZAK, S., OGRODOWCZYK, A. (2015): New-build gentrification in the post-socialist city: Łódź and Leipzig two decades after socialism. Geografie, 120, No. 2, pp. 164-187. - This contribution focuses on the role of new-build gentrification in the socio-spatial re-differentiation of shrinking second-tier post-socialist cities in Germany and Poland, countries that differ in terms of the pace and character of post-socialist transition. Our main goal is to compare and contrast the unfolding of new-build gentrification in different post-socialist settings with the examples of new-build gentrification known from international studies that mostly cover "Western" cities. One of the main findings of our study is that the tempo and scale of new-build gentrification is sensitive to the pace of post-socialist transformations and to institutional contexts. Regarding the international debate on newbuild gentrification, our findings from Łódź and Leipzig highlight a rather distinctive mode of the process. Despite the undeniable similarities with the spatial patterns detected by previous studies illustrating the "Western" contexts, the new-build gentrification detected in our case cities points to different economic roots as well as specific social consequences. Irrespective of identified differences between Leipzig and Łódź, the new-build gentrification appears to be economically independent from the former (other) forms of gentrification and its dynamics. KEY WORDS: post-socialist city - new-build gentrification - Leipzig - Łódź - Central and Eastern Europe.
\end{abstract}

The research reported in this article was made possible in part through the financial support of the Polish National Science Center (Research Grant No. 2011/03/B/HS4/02302).

\section{Introduction}

The downfall of socialism had a dramatic impact on the pace and character of urban development in Central and Eastern Europe. The post-socialist states and their cities introduced new, predominantly market-oriented, institutional arrangements to regulate the modes of urban governance and spatial planning. The changes induced by the transition were particularly palpable in the historical core of the post-socialist city (Enyedi, Kovacs, eds. 2006; Haase et al., eds. 2012; Scott, Kuhn 2012). Even though the central areas of Central and Eastern Europe cities had witnessed gentrification-like processes already under socialism (Hegedüs, Tosics 1991), the reintroduction of the market economy, as well as the privatization and restitution of housing and land in the early 1990 s, created the fertile ground for capital-led, profit-seeking redevelopment (Smith 1996, Kovács 1998, Sýkora 2005). Unfortunately, despite numerous works revolving around gentrification (Feldman 2000; Sýkora 2005; Nagy, 
Timar 2012), redevelopment and regeneration (Kiss 2002; Scott, Kuhn 2012), inner city commercialization (Temelová 2007), and demographic change (Haase et al., eds. 2012; Grabkowska 2012), it seems that most of the available works lack a convincing empirical underpinning that would illustrate the nature of social and physical upgrading of historical urban centers, its actors and outcomes (Kovacs, Wiessner, Zischner 2012). Then, the aim of this study is to illustrate the tempo, structure and local patterns of new-build gentrification in the large Central and Eastern Europe city, and how this process alters the inherited socio-spatial landscape of the central areas. In doing so, we endeavor to compare and contrast the process and patterns of new-build gentrification, a phenomenon emphasizing the role of new housing developments in socio-spatial upgrading, that unfolds in different post-socialist settings with the examples of the phenomenon known from the "Western" city.

Existing studies on the gentrification (regeneration) of historical urban centers in Central and Eastern Europe cities give some pointers to the pace and character of the phenomenon in the last two decades. As the issue has been discussed elsewhere (for the recent review see Haase et al., eds. 2012; Kovacs, Wiessner, Zischner 2012), we will limit our discussion to key aspects of sociospatial upgrading in urban centers. The pace and scale of socio-spatial upgrading has been context sensitive and followed the tempo of systemic changes in the region, the pace of the region's integration with global markets. In the first decade after transition, with the exception of the former East Germany where gentrification and regeneration flourished already in the 1990s, especially in Berlin (Bernt, Holm 2005), the upgrading of the city centers in the other capitals of the "fast-track" reforming countries ${ }^{1}$ was rather slow (Sýkora 2005), and usually unfolded in a piecemeal fashion (Kovacs 1998; Brade, Herfert, Wiest 2009; Marcińczak, Sagan 2011). The phenomena gained momentum in the new millennium (Scott, Kuhn 2012), and gentrification and regeneration are generally more advanced in the capitals of the former socialist states than in the second/third tier cities (Brade, Herfert, Wiest 2009); yet, the processes are present in the former too (Haase et al., eds. 2012; Nagy, Timar 2012; Kaczmarek, Marcińczak 2013; Murzyn-Kupisz 2013). However, so far, it appears that the socio-spatial upgrading of historical urban centers in Central and Eastern Europe has not reached the scale western scholars (Smith 1996) predicted more than a decade ago (cf. Kovacs, Wiessner, Zischner 2012).

The processes of gentrification and redevelopment in the post-socialist city could be triggered by different groups of "pioneers" (young households, students, artists, etc.) (Chelcea 2006; Grabkowska 2012; Haase et al., eds. 2012) as well as by corporate investors and developers (Badyina, Golubchikov 2005). The phenomena are sensitive to the local institutional context and, sometimes,

1 The term "fast-track reforming countries" refers to the former socialist countries that were leading in transition and that joined the European Union in 2004: the Baltic States (Estonia, Latvia and Lithuania), the former Czechoslovakia, the former East Germany, Hungary, Poland and Slovenia (Hamilton, Andrews, Pichler-Milanović, eds. 2005). Interestingly, even in this relatively homogenous group, the tempo and depth of systemic socioeconomic and political changes differed. Essentially, the process was much more rapid in the former East Germany than in the other countries. Also the scale and forms of housing privatization and restitution reflect different strategies adopted across post-socialist Europe. 
the public sector actively supports socio-spatial upgrading (Bernt 2012). It also seems that new built, often luxurious, residential and office spaces developed by national and international private investors dominate in the regenerated tracts (Cook 2010; Kovacs, Wiessner, Zischner 2012). Finally, whereas some scholars argue that the process of gentrification in the Central and Eastern Europe city simply reflects the wider global phenomenon (Nagy, Timar 2012), there are critical voices questioning such universalist assumptions (Sýkora 2005, Chelcea 2006, Gentile, Salukvadze, Gogishvili 2015).

As there still is an empirical gap in the studies on the socio-spatial upgrading of the urban centers in the Central and Eastern Europe city, and bearing in mind that the pace and scale of gentrification/regeneration after socialism are context-sensitive and that the processes often entail new built fabric, this contribution maps and analyzes new-built gentrification in two second-tier post-socialist cities (Łódź and Leipzig) that represent different institutional contexts and the pace and character of systemic transformations after 1990 . Referring to the most commonly studied aspects of new-build gentrification in the already rich body of work on this form of socio-spatial upgrading, we chose the following dimensions of the phenomenon for closer examination: (1) the economics of new-build gentrification; (2) the geography of the process; and (3) the social profile of the gentrifiers. Unfortunately, the structure and quality of available data allow us to compare both cities on a rather general level only ${ }^{2}$. Nonetheless, we believe that the framework adopted to analyze the process and patterns of new-build gentrification in the two cities is sufficient to identify key similarities and differences. The following section presents the current debate on new-build gentrification in the "Western" city, where the process was first identified. We then elaborate on the geography and economy of new-build gentrification in Łódź and Leipzig, and on the socio-demographic profile of the consumers. Finally, we will interpret the forms of new-build gentrification identified in the two cities in the wider theoretical and empirical context known from the "Western" city.

\section{Researching new build gentrification}

Originally gentrification was developed as an analytical concept to describe and to explain the shift towards an upgrading of neighborhoods after a long period of declining and decay (Glass 1964). In contrast to other concepts like

2 Because of the different structure and quality of the available data for each city we decided to compare both cases on the level of general synopsis within a comparative framework reflecting key aspects of new-build gentrification. Apart from interviews conducted with corporate developers in Łódź, the paper does not include original data. The interviews in Łódź were conducted by The Scientific Association of Students of Spatial Management (University of Łódź) in October-November 2012. In total, representatives of twelve corporate developers investing in new residential developments were interviewed. We then primarily rely on available statistical information on population, housing, rent prices and new construction activities from public institutions and administrations in the two cities. We also use information from unpublished materials from real estate institutions (Łódź) and from an external executed evaluation of real estate offers (Leipzig; Schneider 2012). 
reurbanization or regeneration, gentrification research focuses on the analysis of the social consequences and conflicts of such changing urban trends (Wyly, Hammel 1999). In more than 50 years of gentrification research the aspect of displacement as an effect of the economic strategies of homeowners and investors became a crucial attribute of gentrification (Slater 2009). Whereas most urban research has defined gentrification as the process of upgrading of formerly neglected houses and neighborhoods, recent research extends the concept's definitional scope to include new construction activities: "In the last decade the designer apartment blocks built by corporate developers for elite consumption have become as characteristic of gentrified landscapes as streetscapes of lovingly restored Victorian terraces." (Shaw 2002, p. 44)

It has only been rather recently that a more general and abstract understanding of gentrification has become acknowledged by urban scholars (Davidson, Lees 2010), but there remain heated debates surrounding it (Hamnett 2003, Butler 2007). According to the broad definition gentrification is understood as a process involving (1) reinvestment of capital, (2) social upgrading of locale by incoming high-income groups, (3) landscape change, and (4) direct or indirect displacement of low-income groups (Davidson, Lees 2005). Consequently, although some argue that, due to the absence of direct displacement, new construction does not fall into the category of gentrification (Lambert, Boddy 2002; Hamnett 2003; Boddy 2007), we believe that it is rational to include newbuild developments into the framework of gentrification research. Such reasoning is also reflected in a wide range of studies that picked up the concept of new-build gentrification to describe new urban trends in cities like London (Davidson, Lees 2005, 2010), Montreal (Germain, Rose 2000; Rose 2002), in Swiss cities (Rerat et al. 2010) or Berlin (Holm 2010; Marquardt et al. 2013), but also in second-tier West European cities like Newcastle (Cameron 2003), Glasgow and Rotterdam (Doucet, van Kempen, van Weesep 2011) or, outside the West European/North American context, in Shanghai (He 2008), Cape Town (Visser, Kotze 2008) and Tokyo (Lützeler 2008). In post-socialist Europe, although new-build residential projects have been discussed in the works on socio-spatial change in the post-socialist city (Badyina, Golubchikov 2005; Cook 2010; Kovacs, Wiessner, Zischner 2012), new-build gentrification has not been studied systematically.

In many publications, new-build gentrification is highlighted as part of the "mutation" (Lees, Slater, Wyly 2008), "diversification" (Butler, Lees 2006), or "multiple geographies" of gentrification (Rerat et al., 2009). In other words, there is no clear definition of new-build gentrification, however, a rich body of work employs the term to describe socio-spatial upgrading in urban centers. To systematize the state of the art on new-build gentrification we will recapitulate the findings of current research on the economic, social and geographical dimensions of the phenomenon.

Economics of new-build gentrification: Some researchers have highlighted the difference between the modes of investment present in "classical" gentrification (involving the renovation of existing housing resources) and new construction. Butler and Lees (2006), in their study on London, argue that newbuild gentrification involves a higher financial investment in the neighborhood than previous waves of gentrification. The shift from individual renovation to 
corporate investments signified the transition from pioneer-driven gentrification to a more corporate second wave (Warde 1991). Current gentrification dynamics that were coined as global urban strategy (Smith 2002) marked the beginning of the third wave. The third-wave gentrification has a stronger integration with national and global capital markets and an "intensified financialization of housing" (Lees, Slater, Wyly 2008). The reinvestment of capital in and through these new-build developments is linked to the financial markets in two ways: through the investment by corporate developers and through loans for the purchase of the apartments (Davidson, Lees 2005). In the literature, the economics of new-build gentrification are presented as major investments by corporate developers with strong ties to the financial market (Smith 2002, Davidson 2007).

Social upgrading and displacement in the context of new-build gentrification: Most studies on new-build gentrification grapple with the issue of displacement. Nevertheless, some studies have identified some forms of displacement that new-build gentrification may bring about: (1) indirect displacement as a consequence of "price shadowing" (Lambert, Boddy 2002); (2) displacement pressure caused by the transformation of the neighborhood's infrastructure and service provision (Rérat et al. 2010); and (3) sociocultural displacement of long-standing residents when gentrifiers take control over local community structures and local governance resources (Davidson, Lees 2010). In other words, displacement caused by new-build gentrification is discussed as a secondary effect in adjacent neighborhoods. As Lambert and Boddy (2002, p. 18) argue: "Rising rents and prices may therefore trigger secondary processes of displacement." To conclude, direct displacement is not seen as a key feature of new-build gentrification, but other forms of displacement, as side-effects, are usually traced in surrounding neighborhoods.

Because of this indirect and exclusionary character of displacement most case studies on new-build gentrification use the term "gentrification" as a metaphor for the upgrading of urban centers by higher professionals (Hamnett 2003). Like "classical" gentrification, new-build gentrification implies a transformation of a neighborhood's social composition. In the case of new-build gentrification, studies from global cities depict the gentrifiers as two groups. One of them, usually involved in super-gentrification, is represented by "globally connected but occupationally localized" business-class executives (Butler, Lees 2006). Their investment in expensive property is based on the super-profits from the global financial world. But these new gentrifiers are not only characterized by very high salaries and the ability to buy expensive properties, but also by different lifestyles compared to traditional middle class gentrifiers: "The super-gentrifier is a different species, $\mathrm{s} /$ he has more conservative values, is focused on social reproduction and is less interested in socio-cultural diversity. (They) like the idea of social involvement but not social mixing." (Butler, Lees 2006, p. 483f) The other group of new-build gentrification consumers recruits from the (upper) middle-class - young and highly educated post-industrial urban professionals being a good case in point (Davidson 2007). In the same vein, works on newbuild gentrification in second/third tier cities describe gentrifiers as the local elite from the financial, technological or service sector, better-off residents who seek socially homogeneous and, in some cases also expensive, estates and 
apartment buildings in urban centers (Rérat et al. 2010). Then the consumers of new-build gentrification could be define as a relatively diverse group of better-off (ranging from the super-rich to the middle class), defined by their occupational position (socioeconomic status) rather than by cultural preferences or the aspiration to reside in historical buildings and/or neighborhoods.

Geography of new-build gentrification: Up to this point, research on newbuild gentrification has not provided us with a systematical analysis of the spatial contexts of this trend. However, there is a narrative of colonization of entire urban areas (Smith 2002; Davidson, Lees 2010). The literature review reveals some typical spatio-temporal patterns. Referring to the process of supergentrification, Butler and Lees (2006) highlight "highly restricted quarters in the central and inner city" as playground for new-build gentrification. Then the concept of super-gentrification draws attention to a chronologic relation to former gentrification dynamics; Lees (2003, p. 2487) defined the process as transformation of "already gentrified, prosperous and solidly upper-middleclass neighbourhoods into much more exclusive and expensive enclaves". The studies on the phenomena of new-build gentrification in Berlin used the same argument, and showed that the closing rent gaps in old housing stock facilitated investment into new construction in already gentrified neighborhoods (Holm 2010). In addition, Rose discusses the construction of new-build "infill" housing in already-gentrified areas in her studies in Montreal (Germain, Rose 2000; Rose 2002). Nonetheless, less prestigious areas also attract new-build gentrification. In London new residential developments are pushing gentrification into the remaining working class neighborhoods and ultra-marginal areas (Davidson 2007). Also former industrial brownfield areas are often redeveloped for residential use (Cameron 2003; Davidson, Lees 2010). Recapitulating the arguments given by previous research, new-build gentrification can occur as small scale infill housing in already gentrified neighborhoods or as larger scale brownfield development in central areas, or as redevelopment of poor neighborhoods throughout the city.

\section{Setting the scene}

The intensity of gentrification, and thus of new-build gentrification, hinges on globalization and liberalization of society and the economy (Smith 2002), but the pace and character of gentrification are also sensitive to inherited urban structures and institutional milieus. In Łódź, the first decade after the collapse of socialism, and especially the early 1990 s, brought about a total economic breakdown. The city's main economic base - the textile industry - collapsed, unemployment skyrocketed, and demographic shrinkage began. Consequently, the city lost approximately 140,000 people (approximately $15 \%$ of the 1989 population). Depopulation and the associated rise in vacant dilapidated housing prevailed in the inner-city, while the suburban areas and the peripheral housing estates, including those constructed under socialism, gained new residents. Although the city managed to reinvent itself, attracting foreign investment in the manufacturing industry in the late $1990 \mathrm{~s}$, a noticeable reversal of the economic decline only came after Poland's accession to the EU in 
2004. Unfortunately, economic growth has not stopped population shrinkage. Interestingly, a comprehensive housing policy emphasizing an urgent need of urban renewal was formulated no sooner than in 2012.

Extensive deindustrialization and dramatic population loss caused by emigration to western Germany, suburbanization, and falling birth rates have meant that most East German cities experienced shrinkage. Leipzig suffered a loss of more than 15 per cent of its population, coupled with high rates of unemployment (Kabisch, Haase, Haase 2010). State-led renewal programs and tax incentives for private investment created a paradox: while housing demand was shrinking, new construction took place in the suburban areas of Leipzig. Vacancy rates of up to 20 per cent (Stadt Leipzig 2009, p. 15) even in modernized buildings, the demolition of prefabricated housing estates, and a consistently low rent price level characterized the housing market at the beginning of the new millennium. Since 2000, however, a reversal of these trends has been interpreted as emerging reurbanization (Herfert 2002; Kabisch, Haase, Haase 2010). Through growing intraregional in-migration and a strong decrease in outmigration, the migration balance turned positive (Haase, Haase, Kabisch 2005).

The case study cities, Łódź and Leipzig, well illustrate the effects of socialist urban development in cities that were not heavily damaged during WWII. It suffices to say that the urban centers of Łódź and Leipzig, with some exceptions, were left to decay under socialist rule and, as in many Central and Eastern Europe cities (cf. Sýkora 2005; Nagy, Timar 2012), a real rent gap emerged in the 1990s. However, contrary to the more prosperous cities in the region, Łódź and Leipzig were rapidly losing population, which impeded the pace of socio-spatial upgrading. Despite those similarities, there are marked differences between the institutional contexts of the two cities. Whereas in most post-socialist countries the restitution of housing and land to the former owners or their heirs was regulated in the 1990s (Blacksell, Born 2002), in Poland an act clearly regulating property restitution has not been issued so far. Interestingly enough, Poland and the former East Germany represent the most divergent approaches to restitution in Central and Eastern Europe; in the latter country the issue was regulated already in 1990 (Moszyńska, Moszyński 2012). Also the cadastral system has not been implemented in Poland yet (Kaczmarek, Marcińczak 2013). Differences in regulations on property restitution may potentially influence the course of gentrification in the two cities; according to Sýkora (2005), the restitution of inner-city property in Central and Eastern Europe cities appears to have more influence on gentrification than the process of privatization.

\title{
4. Łódź
}

\author{
4.1. Spatial patterns of new-build \\ gentrification in Łódź
}

The division of Łódź's development path after 1989 into two periods (before and after 2004) closely matches the fundamental shift in the local patterns of new housing unit construction. In the first period (1995-2004), corporate 
Table 1 - New residential developments in Łódź 1995-2012

\begin{tabular}{|lcccccccc|}
\hline Areas & \multicolumn{2}{c}{ New housing units } & \multicolumn{2}{c|}{ New luxurious units } & & \multicolumn{2}{c|}{$\begin{array}{c}\text { Share of new } \\
\text { luxurious units }\end{array}$} \\
\cline { 2 - 3 } & $1995-2004$ & $2005-2012$ & & $1995-2004$ & $2005-2012$ & & $1995-2004$ & $2005-2012$ \\
\hline Historic core & 88 & 4,139 & & 78 & 296 & & 88.64 & 7.15 \\
Inner city & 126 & 1,896 & & 0 & 0 & & 0.00 & 0.00 \\
Łódź & 2,447 & 10,164 & & 110 & 343 & & 4.50 & 3.37 \\
\hline
\end{tabular}

Source: Materials from corporate developers and the City of Łódź Office

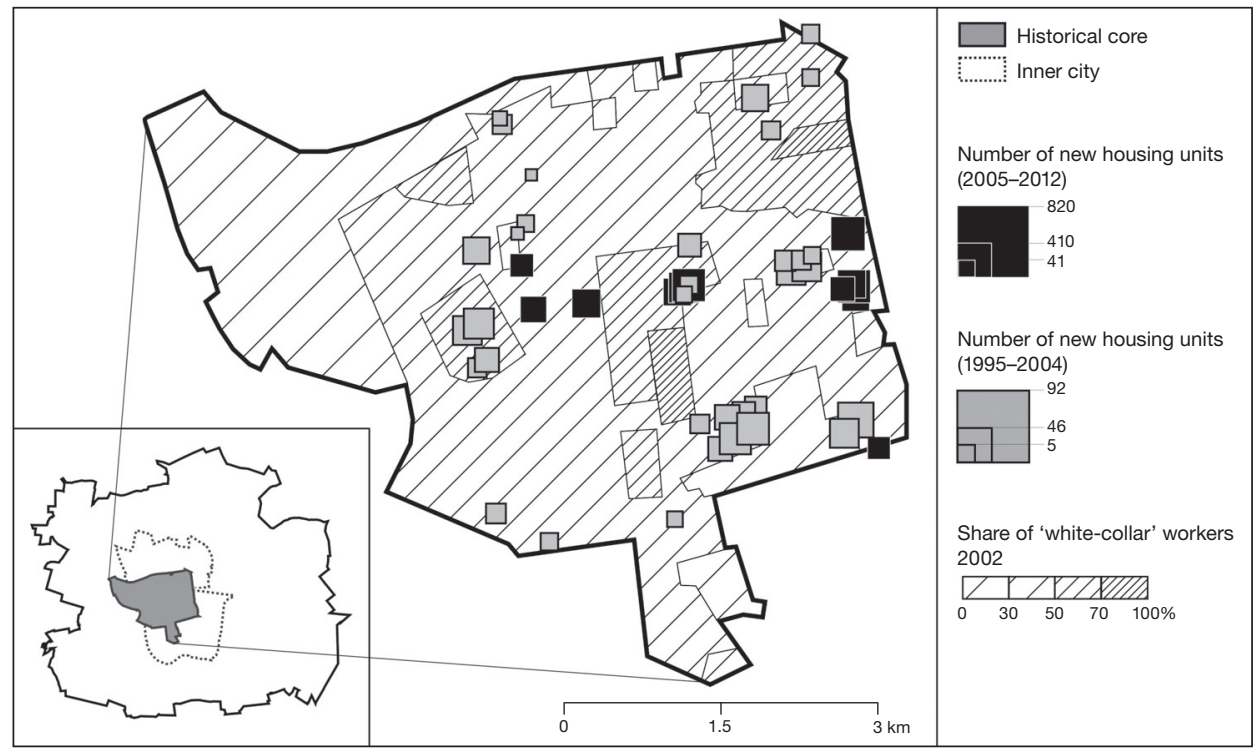

Fig. 1 - Newbuild gentrification and socio-spatial fragmentation in the historical core of Łódź. Source: Materials from corporate developers and the City of Łódź Office.

developers concentrated their attention outside the urban center, but the majority of new housing in the historical core belonged to the luxury segment ${ }^{3}$ (Table 1). In the early 2000 s the trend changed radically. The central districts became the prime target for Polish and international corporate developers. From 2005 to 2012, the historical core was the site of 41 percent of the total number of new housing units. Outside the core, but still in the inner-city, a zone of pre-WWII housing that separates the historical core from blocks of flats housing estates, an additional 18 percent of the total number of new housing units were constructed (Table 1). However, new housing units constructed in the urban center after 2004 are no longer limited to the luxury segment.

3 By luxury new housing units we understand those units where the price per square meter was one standard deviation higher than the mean price of new housing units in Łódź in a given year. Such definition implies that luxurious new housing units may also be present in more affordable housing developments. 


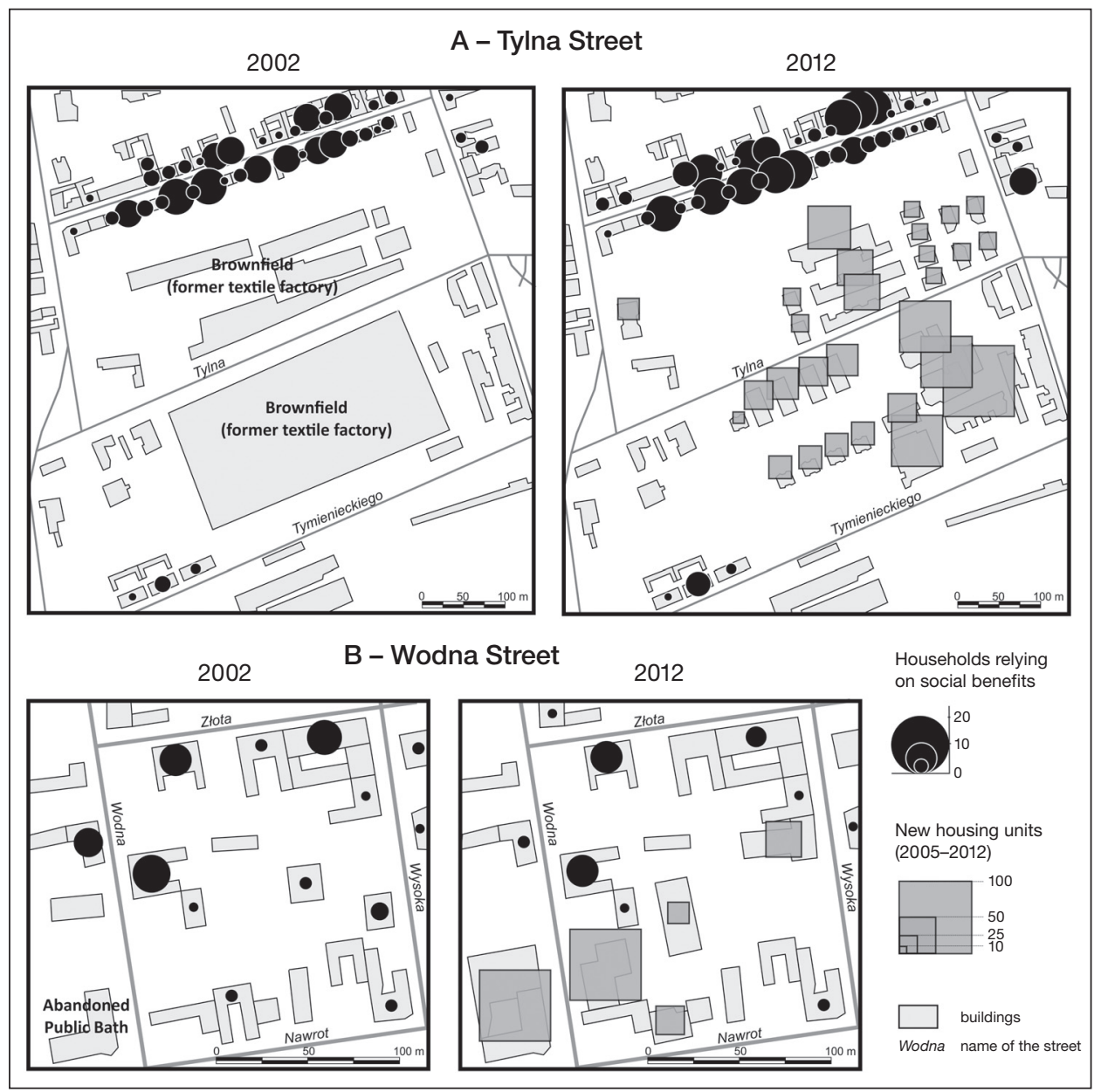

Fig. 2 - Newbuild gentrifaction and neighborhood socioeconomic polarization. Source: Materials from corporate developers and the City of Łódź Office.

To trace the effects of new-build gentrification on the existing social fabric of Łódź's central areas, we looked at the exact locations of new housing units in the local socio-spatial context. The residential complexes constructed by corporate developers before and after 2004 are visualized on a map illustrating the social status of the historical core's neighborhoods in 2002 (Fig. 1). The category "white-collar" workers (managers, senior officials and professionals) was distinguished from the rest of the economically active population, including the unemployed, and indicates the portion of the population with high social status. A brief inspection of Figure 1 suggests that the socio-spatial structure of the core area has a mosaic pattern. It also appears that new-build gentrification increases the socio-spatial diversity of the district. In other words, in the first two decades after transition, a new residential fabric was created in both high social status and low social status neighborhoods. 
In areas inhabited by a population with prevailingly low social status, newbuild gentrification may induce micro-scale social and physical upgrading that morphs into neighborhood social polarization (cf. Marcińczak, Sagan 2011). Intriguingly, a similar effect, growing social heterogeneity, is caused by new residential developments in other parts of the post-socialist city (Sýkora 2007, 2009; Marcińczak, Gentile, Stępniak 2013). In Łódź, new-build gentrification is often juxtaposed with buildings where low social categories are over-represented - households solely relying on social benefits (Fig. 2). In other words, even if located on former industrial brownfields (Fig. 2, panel A) or on the site of demolished tenements (Fig. 2, panel B) leads to fundamental changes in the social composition of neighborhoods. The redevelopment of former textile factories into a relatively large and luxurious residential project (almost 1,000 new housing units) resulted in a very specific social mix of the former enclave of poverty. Furthermore, as Figure 2 (panel B) illustrates, new-build gentrification in the post-socialist city may also involve some forms of direct displacement. In the presented case-study area, displacement was supported, and actually made possible, by the direct involvement of the public sector - residents of low-quality municipal tenements were relocated by local authorities, the buildings were demolished and the plots sold to a developer.

\subsection{Economy of new-build gentrification}

Owing to the underdeveloped mortgage market (Roy 2008), relatively high inflation and unemployment, and a slow increase in wages, the housing sector grew slowly in the first decade after transition. Along with the economic growth in the new millennium, the mortgage market and housing construction sector thrived in Poland, especially after 2004 (Raport o sytuacji na rynku 2012). According to the interviews with developers, the housing market in Łódź, a shrinking city, is not easy - in principal, salaries are much lower here than in the capital city, or in other major cities in Poland, and the labor market is more limited (especially high-paying jobs). On the other hand, despite population shrinkage, the housing shortage in Łódź is among the most acute in Poland, sustaining substantial demand for new housing (Książczyk 2013). The years after 2005 have brought about the dominance of corporate developers ${ }^{4}$ in the supply of new housing. In the new millennium, corporate developers refocused on the inner-city and on the historical core, where decayed industrial sites and empty plots offered a potential rent gap to capitalize on. The main reasons why corporate investors decided to develop new housing in the historical core of Łódź were, first and foremost, the low prices of serviced and well accessible land/plots, but also green areas and social infrastructure.

Regarding the typical examples of new-build gentrification, the first luxury building with apartments for sale in the historical core of Łódź - Solaris, with

4 In the 1990s, there were only four corporate developers raising new housing units in Łódź. In 2012, 70 different developers were investing in Łódź: individuals, banking companies and large construction enterprises. Although the companies with Polish capital dominate, few foreign investors are present and they come from Australia, Great Britain, Ireland, Italy or USA. 
a $140 \mathrm{~m}^{2}$ penthouse - was finished in 2002 . Despite the enduring unfavorable economic conditions for the primary residential market, developers have continued to invest in the central areas of Łódź. Their activities have been generally supported by the local government. By emptying and selling or leasing serviced plots in the urban center, public actors actively promote the redevelopment of the area - former factories and almost fifty percent of the pre-war tenements in the historical core are owned by public institutions.

Regarding the prices, in 2005 the average price of a new housing units in Łódź was $732 \mathrm{EUR} / \mathrm{m}^{2}$. But in the case of luxury housing in the central zone, the prices were as high as $1,100 \mathrm{EUR} / \mathrm{m}^{2}$ and more. At the same time, the average monthly salary in Łódź was 623 EUR (enough to buy only $0.85 \mathrm{~m}^{2}$ in a standard apartment). In 2009 a marked slowdown turning into decline hit the Polish real estate market. Interestingly enough, the developers investing in Łódź kept launching new projects. After 2008, the date when the global crisis started, the number of new luxury and expensive residential investments located in the city center increased - e.g. the Platinum building from 2009, constructed by the main street (Piotrkowska St.). The price of an apartment there ranged from 2,641 to $4,448 \mathrm{EUR} / \mathrm{m}^{2}$ - the average price of a new housing unit in the historical core was $1,460 \mathrm{EUR} / \mathrm{m}^{2}$. The prices of real estate in the core are still the highest in the city, though they do vary. When the Polish government introduced a subsidy program ${ }^{5}$ for young families buying their first apartment, many developers adjusted their plans and include new housing units meeting the program's criteria. Accordingly, even the luxury projects such as Barciński Park (Fig. 2, panel A), may contain some new housing units that are of similar price to those in the outer zone. However, the declining prices of new housing units in 2010-2012 did not make them more accessible to the ordinary resident. In 2012, the average price of one $\mathrm{m}^{2}$ of a new housing unit was 1,143 EUR, while the average monthly salary was 873 EUR (the equivalent of $0.76 \mathrm{~m}^{2}$ in a new apartment). Moreover, mortgages became increasingly more difficult to obtain as banks largely withheld, usually cheaper, mortgage loans denominated in foreign currencies and started to demand higher down payment (Raport o sytuacji na rynku 2012).

\subsection{Social Structure of the Gentrifiers}

Hard empirical data on the socio-professional structure of the residents of new housing units is still missing. However, there are some pointers indicating the characteristics of those who buy new housing in the historical core.

5 The program Rodzina na swoim was launched in 2006 to enable middle-income young families to purchase their first own apartment. Essentially, in each city and rural area, a certain price level for new and existing apartments was set and adjusted every year. Apartments and single family houses that meet the price criteria are eligible for subsidized mortgages when purchased by a young family (a couple that is married and does not own an apartment/house); the state pays the interest rate of the mortgage for the first eight years. Nonetheless, families applying for this program have to be eligible to take a mortgage loan first, which means they should have average (or above average) income and a long-term employment contract. 
Assuming that in Łódź the main line of social divisions separates the relatively small socioeconomic elite from a much bigger, albeit varied, group of lower social categories (Marcińczak, Musterd, Stępniak 2012), there is a limited group of contingent buyers. In other words, the gap between the average salary and the price of new housing units in the city center is rather wide and there are generally two potential socio-professional categories with the mean income able to purchase new-build gentrifications: (1) managers and senior officials, and (2) professionals. Increasingly more difficult access to mortgage loans. The fact that the majority of new housing unit buyers relies on mortgages (Raport o sytuacji na rynku 2012), further indicate the relatively "elite" character of the new residential developments. Yet, some, mostly the high-end apartments, are bought by foreign companies to accommodate expats coming to supervise foreign direct investment projects. The interviewed developers also mentioned international, but also domestic, investors who often buy more than one apartment for profit. A similar phenomenon was reported in Prague (Cook 2010), Budapest (Kovacs, Wiessner, Zischner 2012), and Tbilisi (Gentile, Salukvadze, Gogishvili 2015). The development of the IT sector and business process offshoring after 2004 contributed to the steady growth of the group of young professionals starting their employment and family career in the city.

It also seems that the socio-demographic profile of gentrifiers is to some degree co-determined by the $R n S$ state program, and that the young families with or without children are the most common buyers of new housing units. Between 2007 to 2012 , the $R n S$ program enabled more than 4,500 families to take a subsidized mortgage and buy an apartment in Łódź (Raport o sytuacji na rynku 2012). More than 70 percent of the families consisted of adults aged 25-34 (ibid.). Interviews with developers investing in the historical core also support the argument about young families searching for new housing units, especially if the units are eligible for subsidized mortgage. The fact that the flagship redevelopment of a former textile factory building into luxury lofts turned out to be a major investment failure -approximately 70 percent of the apartments remained unsold even though the project ended up at a trustee's auction - implies that there is a limited demand for non-standard luxury housing, i.e., apartments that are not designed for families with children. In other words, even if the number of "transitory urbanites" (students, young "alternative" households) grew in the inner city (Haase et al., eds. 2012), this group of contingent gentrifiers is not significant among the consumers of new-build gentrification. Then, even if transitory urbanites are willing to stay in the inner city, they simply do not necessarily have the required resources (income and a stable job) to take a mortgage and buy a new-build apartment.

\section{Leipzig}

\subsection{Geography of new-build gentrification}

Despite a relaxed housing market, the gentrification debate reached the political and public discourses in Leipzig twenty years after transition. Especially in the inner city neighborhoods, the population growth of the last years 


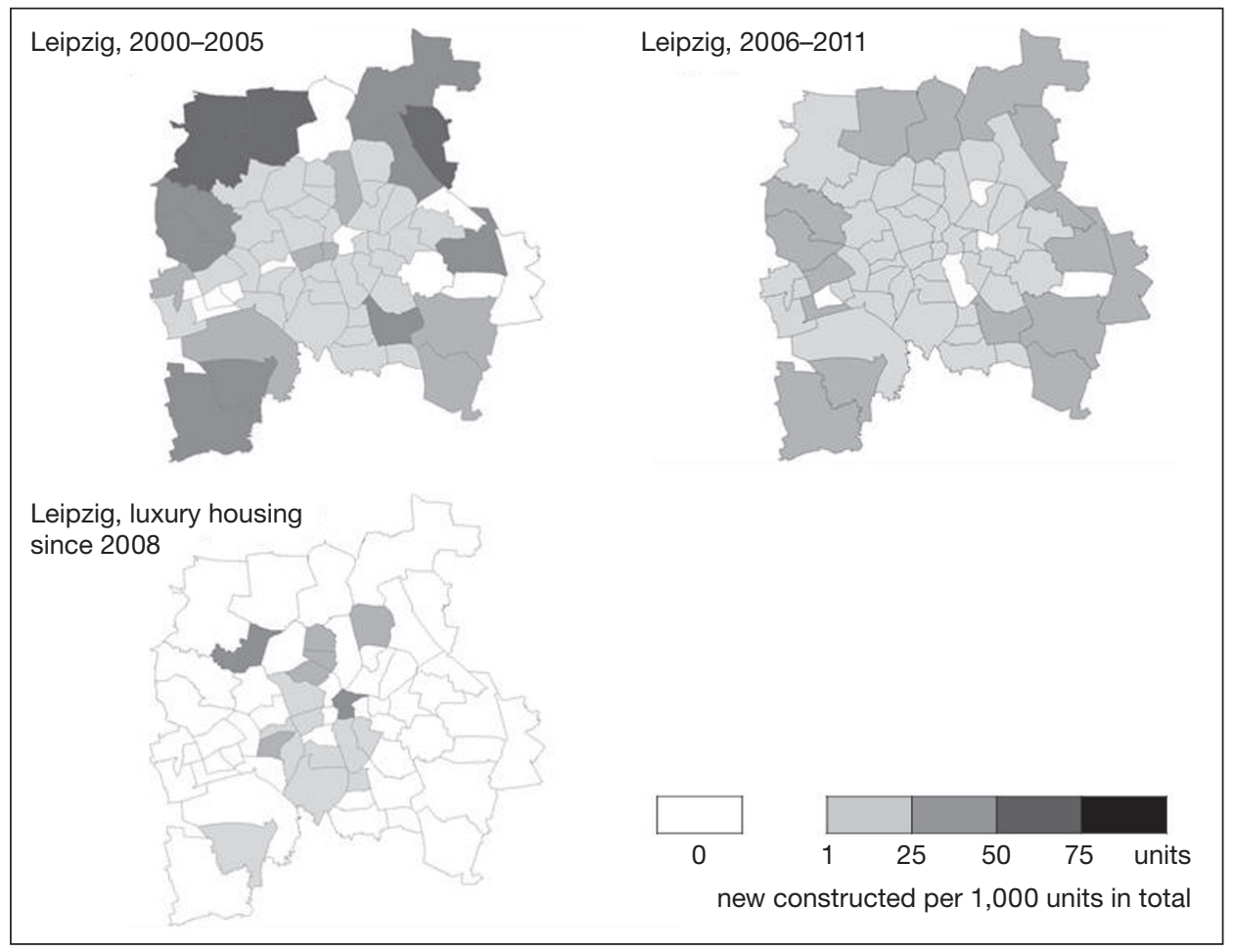

Fig. 3 - Spatial pattern of new construction activities in Leipzig (2000-2011).

Source: Schneider 2012.

stimulated demand for housing and caused rising rents. In his study on recent gentrification discourses, Dieter Rink (2012) identified two aspects of this housing change: the reduction of affordable housing for the urban poor, and the emergence of a highly priced and exclusive housing segment. "Gentrification expresses itself in conversion and price increases in single locations (industrial lofts, former military areas), luxury modernizations of old housing, and in high-quality new construction (townhouses, exclusive apartment houses), all attendants on social upgrading. As opposed to former modernizations, current upgrading is addressed to specific social groups." (Rink, 2012) This trend of space-specific investment in exclusive housing segments is visible in the spatial patterns of new construction activities in Leipzig. Although there is a citywide decrease in construction activities, we can identify a trend towards new construction in the most popular neighborhoods.

Recent research has highlighted a rising number of high-price housing projects in Leipzig and counted 43 luxury projects with more than 2,500 housing units realized or under constructions since 2008. 18 projects of these projects with more than 600 housing units were identified as new construction (Schneider 2012). This new luxury housing trend in Leipzig has an impact on the geography of investment. New construction activities in Leipzig shifted from the outskirts to the city center in the last decade. During the first years of 
the new millennium, the highest number of new constructions was realized in the peripheral districts in the north (Wiederitzsch, Eutritzsch and Lindenthal) and in the west (Mölkau, Engelsdorf and Heiterblick). Only one inner city neighborhood (Zentrum West) was included in the top ten list of new construction areas. Looking at the new construction activities between 2006 and 2011, the focus of investment fell on two inner city neighborhoods (Zentrum West and Gohlis-Süd) are ranked in the top ten for construction activities. When one focuses on the high price housing projects in the last years, nearly all construction activities are concentrated in the inner city areas (see Fig. 3). Matthias Bernt attributes these developments to the changing planning principles after socialism (Bernt 2009, p. 75).

\subsection{Economy of new-build gentrification}

The areas with most high-end new construction have the highest rent levels and the most expensive prices for condominiums in modernized housing. With the exception of Schleußig with only 14 exclusive waterfront dwellings in a single project ("Elsterterrassen"), all newly constructed luxury buildings were realized or planned in neighborhoods with rent and purchase prices over the citywide average. In average the price for newly built apartments is 25 per cent (or 550 Euro per square meter) higher than for apartments in modernized old housing. One could argue that the locally closed rent gap for the old housing stock constitutes a precondition for investment in high-priced housing. Most of the historical buildings in the areas targeted by high-priced investments are already modernized and have a high standard of housing maintenance. Furthermore, most new projects are placed near parks, green areas or close to the inner city Karl-Heine canal (Schneider 2012).

Most of the newly constructed townhouses, lofts and residences are offered for sale. This is especially interesting, as - until now - Leipzig's housing market

Table 2 - Newly constructed luxury housing in selected areas in Leipzig since 2008

\begin{tabular}{|c|c|c|c|}
\hline \multirow[t]{2}{*}{ Area } & \multicolumn{2}{|c|}{ Newbuild luxury housing } & \multirow{2}{*}{$\begin{array}{c}\text { Modernized old } \\
\text { housing }\end{array}$} \\
\hline & $\begin{array}{c}\text { Number of housing } \\
\text { units }\end{array}$ & $\begin{array}{l}\text { Price for apartments } \\
\text { in Euro } / \mathrm{m}^{2}\end{array}$ & \\
\hline Plagwitz & 164 & 2,700 & $2,200-2,400$ \\
\hline Gohlis-Süd & 157 & 2,850 & $>2,400$ \\
\hline Zentrum-Ost & 131 & 2,300 & $2,200-2,400$ \\
\hline Zentrum-West & 121 & 3,000 & $>2,400$ \\
\hline Wahren & 33 & 2,200 & $2,200-2,400$ \\
\hline Gohlis-Mitte & 30 & 2,000 & $2,200-2,400$ \\
\hline Reudnitz-Thonberg & 19 & 2,350 & $2,200-2,400$ \\
\hline Schleußig & 14 & 2,600 & 1,900 \\
\hline$A l l$ & 669 & 2,800 & 2,250 \\
\hline \multicolumn{3}{|c|}{ Leipzig average for apartments in modernized old housing } & 2,150 \\
\hline
\end{tabular}

Source: Stadt Leipzig 2012, p. 35 
is characterized by a strong dominance of rentals. new housing unit therefore point towards some changing configurations in tenure structures, too. The prices vary between 2,300 and $3,800 \mathrm{Euro} / \mathrm{m}^{2}$. At around $2,800 \mathrm{Euro} / \mathrm{m}^{2}$, the average price for newly constructed housing is clearly higher than the average price for modernized apartments in Leipzig (2,150 Euro/ $\mathrm{m}^{2}$; Table 2). In some studies on high-price housing in Leipzig it is assumed that most sales cater to private investors searching for "concrete gold" (German investor jargon for real estate which offers security in times of crisis). Based on prices and the advertised mean floor space area (average $92 \mathrm{~m}^{2}$ ) of the projects, the total volume of investment in the luxury housing segment in Leipzig has to be estimated at around 200 million Euros. Most investors are German developers specialized in the field of high-price real estate projects; only a small number of investments are operated by international real estate companies.

\subsection{Social Structure of Gentrifiers}

There are no data available to describe the social structure or the occupation of the purchasers or the inhabitants of the newly constructed luxury housing in Leipzig. Whereas some new build housing units are owner-occupied, the buy to let scheme is more common. The advertised prices can be seen as indirect evidence of the economic wealth of the purchasers and tenants of the newbuild developments. With respect to the German cultural stance towards homeownership as a long-term investment (Helbrecht, Behring 2002), it is obvious that most of the new residents have their employment in Leipzig. The new attractiveness of the inner-city neighborhoods is broadly discussed against the background of reurbanization tendencies (Kabisch, Haase, Haase 2010). Studies on Leipzig have identified a rising number of young singles and families moving into the central areas. Since 2000 , more than 40,000 people, especially young, highly educated people, have moved to Leipzig and reduced the amount of vacant housing in the inner city neighborhoods by 15,000 housing units (Rink 2012). To summarize: there has been an increase in housing for high income groups, the trend towards properties for sale indicates solidification of these groups, and there has been an in-migration of young and educated households a portion of the new residents could well be described as young elites.

Additionally, the promotion of most of the new construction projects seems to be directed at young families with the desire for distinctive, high-quality housing. Nearly half of all newly constructed luxury houses was marketed with catchphrases like "green", "garden", "yard", or "park", and communicate a kind of suburban quality in the middle of the city. Another marketing pitch is to emphasize the high and distinct quality of the housing and of the architecture. Names like "Comfort Park Residence", "Solitaire" or "Gohlis Suites" present a kind of value-conscious distinction. With respect to the housing type, the prices, and the spatial context, the newly constructed high-priced housing projects represent a strong contrast to the alternative lifestyles and neighborhoods in Leipzig-Connewitz. Discussed against the background of gentrification, new luxury constructions are dissimilar to neighborhoods with former dynamics of pioneer gentrification. 


\section{Conclusion}

The aim of this paper was to investigate the pace, character, and effects of new build gentrification in second-tier post-socialist cities representing divergent paths of the post-socialist transition. We have also attempted to verify to what degree the new-build gentrification unfolding in Leipzig and Łódź after 1990 resembles this variant of socio-spatial upgrading known from the "Western" city. We have thus scrutinized the economy and geography of new-build gentrification and the socio-demographic profile of those who consume it. One of the main findings of our study is that the tempo and scale of new-build gentrification is sensitive to the pace of post-socialist transformations and institutional contexts. Indeed, the large cities of the former East Germany have been transforming much faster than their cousins in Central and Eastern Europe. Whereas in Leipzig the redevelopment of the historical core was in progress in the mid-1990s, in Łódź a more vigorous regeneration started only a decade later, when the city became more exposed to the global flows of capital and services. Despite this time gap, in both cities the central tracts were the location of luxury housing already in the 1990s. It is difficult to clearly state whether new-build gentrification is a new stage of gentrification in Central and Eastern Europe (Holm, 2010). Even though there is evidence supporting the existence of "classical" forms of social and physical upgrading of the inherited housing stock in the second-tier post-socialist city (Sýkora 2005, Grabkowska 2012; Haase et al., eds. 2012, Kaczmarek, Marcińczak 2013), the results from Łódź and Leipzig seem to support the conclusion that both "classical" gentrification and new-build gentrification simultaneously reshape the socio-spatial structure of the urban centers. Yet, as in Łódź, but also in other post-socialist cities (cf. Kovacs, Wiessner, Zischner 2012; Gentile, Salukvadze, Gogishvili 2015), newbuild projects may actually dominate over traditional forms of socio-spatial upgrading.

In Leipzig and Łódź, the process of new-build gentrification has distinctive spatial patterns. Similar to the former industrial cities in Western Europe (Cameron 2003), numerous brownfields in the central tracts have attracted the attention of corporate developers. Especially for larger projects with 200 housing units or more, investors are dependent on the presence of large vacant plots or demised industrial facilities to realize construction. In Łódź, unlike in Leipzig, the attractiveness of post-industrial sites also stems from their clear property rights ${ }^{6}$; Poland is the only Central and Eastern Europe country that has not yet introduced a restitution act (cf. Moszyńska, Moszyński 2012), and, consequently, there are still many built-up plots without clarified property rights in the inner city of Łódź. Piecemeal privatization of public housing to sitting tenants contributed to the fragmentation of property rights. Notwithstanding

6 Many private factories in the historical core of Łódź were nationalized in the late 1940s and the former owners were compensated and the process was legally binding. This was not the case with numerous nationalized tenements, especially those that were owned by Jewish residents killed during world war two. Although many buildings were restituted after 1990, which often took a long time, still fifty percent of the housing stock belongs to, or is administered by, the municipality. 
the comprehensive potential for modernization of historical housing, new-build gentrification that often involves small estates on former industrial sites appears to be the easiest way to invest in real estate and thus the process could be seen as a convenient way to close existing rent gaps. In Leipzig, small scale infills with approximately 10 units that are located in selected modernized neighborhoods are the most common form of new-build gentrification. In other words, the new-build gentrification in Leipzig contributes to a small but distinctive segment of the housing market that capitalizes on a rent gap in a niche. In both case cities, domestic and international corporate developers are the main providers of new-build gentrification. Finally, it appears that in Poland, where homeownership is strongly promoted by the government, the process of new-build gentrification is sensitive to the development of the mortgage market and access to mortgage loans.

Referring to the new-build gentrification's effects on the socio-spatial composition of the inner-city neighborhoods, it seems that they either ossify, rather than supergentrify, the already high social status of selected tracts or, more commonly, contribute to increasing social mix. However, the effects are not ubiquitous. In Łódź the newly emerging forms of new-build gentrification-induced social mix in marginal neighborhoods may be quite far from the healthy blend of socioeconomic groups identified in more prosperous post-socialist cities (Kovacs, Wiessner, Zischner 2012). In other words, at least at the micro-scale, the selective socio-spatial upgrading may bring about "mixed" social polarization, which implies that the consumers of new, often luxurious, housing live just a stone's throw from the low social groups. In Leipzig, the socio-spatial context in which luxury new-build projects are constructed is somewhat different than in Poland; they are primarily "ordinary" neighborhoods with relatively high-quality housing conditions and a middle class population. In other words, new-build gentrification is frequently located in attractive locations - waterfronts or in close vicinity to urban forests and parks. The geography of luxurious projects in Leipzig usually does not overlap with the hotspots of pioneer gentrification; the already-gentrified tracts are not the focus of construction. Even though new-build gentrification largely leads to indirect displacement in "Western" countries (Davidson, Lees 2005), our results reveal that, in its post-socialist variant, the process could also entail direct displacement. This, as we noted in Łódź, is especially likely concerning cooperations between corporate developers and the public sector to redevelop plots with poor-quality social housing. Such forms of social upgrading, but also other forms of gentrification, have not been contested by local residents (yet?).

Due to the lack of hard empirical data, the analysis of the socio-demographic composition of gentrifiers was limited. Nonetheless, the presented results allow us to sketch a simplified profile of new-build gentrification consumers in Leipzig and Łódź. Assuming that the new residential projects in the central districts are generally more expensive than elsewhere - some of them are the most expensive in the city - and that the average salary allows the purchase of a bit more than half a square meter of an average new apartment in the city center, it seems that the contingent residents recruit from the middle class and the local socioeconomic elites. As both case cities are increasingly more exposed to the global flow of investments and labor, some of the new housing, usually 
Table 3 - New build gentrification in Łódź and Leipzig

\begin{tabular}{|llll|}
\hline & Lódź & Leipzig & $\begin{array}{l}\text { Previous new- } \\
\text { build gentrification } \\
\text { research }\end{array}$ \\
\hline Geography & $\begin{array}{l}\text { brownfield redevelop- } \\
\text { ment and infills in } \\
\text { central but usually } \\
\text { low or mixed social } \\
\text { status neighborhoods }\end{array}$ & $\begin{array}{l}\text { brownfield redevelop- } \\
\text { ment and infills in } \\
\text { central and already } \\
\text { modernized neighbor- } \\
\text { hoods }\end{array}$ & $\begin{array}{l}\text { brownfield redevelop- } \\
\text { ments and infills in } \\
\text { central and already } \\
\text { gentrified neighbor- } \\
\text { hoods }\end{array}$ \\
\hline Economy & $\begin{array}{l}\text { rent gap accessibil- } \\
\text { ity due to clarified } \\
\text { property rights }\end{array}$ & $\begin{array}{l}\text { rent gap niche in } \\
\text { relaxed but mostly } \\
\text { modernized housing } \\
\text { market }\end{array}$ & $\begin{array}{l}\text { rent gap in marginal } \\
\text { neighborhoods but } \\
\text { also in already gentri- } \\
\text { fied neighborhoods }\end{array}$ \\
\hline $\begin{array}{l}\text { Social structure } \\
\text { of consumers }\end{array}$ & $\begin{array}{l}\text { middleclass in mar- } \\
\text { ginal neighborhoods, } \\
\text { micro socio-spatial } \\
\text { mix }\end{array}$ & $\begin{array}{l}\text { upper middleclass in } \\
\text { ordinary neighbor- } \\
\text { hoods }\end{array}$ & $\begin{array}{l}\text { local elite (but in } \\
\text { global cities also } \\
\text { international elite) } \\
\text { in already gentrified } \\
\text { areas; (upper) middle } \\
\text { class in marginal }\end{array}$ \\
& & & neighborhoods \\
\hline $\begin{array}{l}\text { Relation to } \\
\text { previous } \\
\text { stages/waves of } \\
\text { gentrification }\end{array}$ & $\begin{array}{l}\text { disconnected from } \\
\text { thification progress in } \\
\text { the city }\end{array}$ & $\begin{array}{l}\text { generally disconnect- } \\
\text { ed from other stages } \\
\text { of gentrification in } \\
\text { the city }\end{array}$ & $\begin{array}{l}\text { the latest develop- } \\
\text { ment stage of gentri- } \\
\text { fication }\end{array}$ \\
\hline
\end{tabular}

new upscale apartments, are consumed by expats from Western Europe. The lesson from Łódź additionally illustrates that the new residential fabric is not limited to the highest segment only, and less affluent, but still middle class social categories (those who have necessary resources to take a mortgage) have potential access to new housing. The pool of potential consumers may be also shaped by public policies such as subsidized mortgages in Poland. Nonetheless, more comprehensive research is essential to provide conclusive arguments on the composition of new-build gentrification consumers in the post-socialist city.

Regarding the international debate on new-build gentrification, our findings from Łódź and Leipzig highlight a rather distinctive mode of the process (Table 3). Despite the undeniable similarities with the spatial patterns detected by previous studies illustrating the "Western" contexts - where new residential projects predominantly concentrate in central areas - the new-build gentrification detected in our case cities points to different economic roots as well as specific social consequences. In both cases, irrespective of identified differences, new-build gentrification appears to be economically independent from the former (other) forms of gentrification and its dynamics. In other words, unlike in the "Western" city (Smith 2002), new-build gentrification in Central and Eastern Europe is not related to the third wave gentrification; gentrification waves appear to conflate in the post-socialist city. As in the West, the process of new-build gentrification in Central and Eastern Europe entails more and less luxurious newbuild constructions and clearly contributes to social upgrading. In Łódź, the newbuild activities in the historical core are not only limited to 
the high(est) segment, and they result from rent gap accessibility in built-up, but also empty, plots with clarified property rights. However, under the conditions of a relaxed housing market, as the Leipzig case illustrates, exclusionary housing projects possibly provide the only opportunity to extend the potential ground rent over the citywide average and new-build gentrification could be interpreted in this case as a rent gap niche.

To summarize, with regard to the economy, geography, and social composition of new-build gentrification consumers, it seems that the process of new-build gentrification in post-socialist Europe is decoupled from gentrification history and stands for a distinctive pathway to produce an extra profit in the housing market. Nonetheless, alike in West European and North American cities (Smith 2002), the new-build gentrification in Central and Eastern Europe is sensitive to the tempo of globalization and the development of financial and mortgage markets. The process of new-build gentrification in the post-socialist city also depends on the state and its activities. Then, in this dimension, the process of new-build gentrification in Central and Eastern Europe appears to follow the trend known from the "Western" city (Cameron 2003; Davidson, Lees 2005). The public sector's participation in urban renewal after socialism could range from the direct contribution of public funds to the physical upgrading of the urban fabric, especially if EU funds are involved (Kaczmarek, Marcińczak 2013), and to tax benefits and other incentives implemented to attract private investors. To conclude, as the gentrification of the historical housing stock in Central and Eastern Europe was rather slow (Sýkora 2005; Kovacs, Wiessner, Zischner 2012), we believe that new-build gentrification, including less luxurious projects available to the middle class, provided the first real rent gaps in the post socialist housing markets and became a target of real market investment strategies.

\section{References:}

BADYINA, A., GOLUBCHIKOV, O. (2005): Gentrification in central Moscow - a market process or a deliberate policy? Money, power and people in housing regeneration in Ostozhenka. Geografiska Annaler B, 87, pp. 113-129.

BERNT, M. (2009): Renaissance through demolitions? Leipzig's response to urban shrinkage. In: Porter, E.; Shaw, K. (eds.): Whose urban renaissance? An international comparison of policy drivers and responses to urban regeneration strategies. Routledge, London, pp. $75-83$.

BERNT, M. (2012): The "Double Movements" of Neighbourhood Change: Gentrification and Public Policy in Harlem and Prenzlauer Berg. Urban Studies, 49, No. 14, pp. 3045-3062.

BERNT, M., HOLM, A. (2005): Gentrification of a particular type. The case of Prenzlauer Berg. In: Atkinson, R., Bridge, G. (eds.): Gentrification in a Global Perspective. Blackwell, London, pp. 106-125.

BLACKSELL, M., BORN, K.M. (2002): Private property restitution: the geographical consequence of official government policies in Central and Eastern Europe. The Geographical Journal, 168, No. 2, pp. 178-190.

BODDY, M. (2007): Designer neighborhoods: New-build residential development in nonmetropolitan UK cities. The Case of Bristol. Environment and Planning A, 39, No. 1, pp. 86-105.

BRADE I., HERFERT, G., WIEST, K. (2009): Recent trends and future prospects of sociospatial differentiation in urban regions of central and eastern Europe: a lull before the storm? Cities, 26, No. 5, pp. 233-244. 
BUTLER, T. (2007): For gentrification? Environment and Planning A, 39, No. 1, pp. 162-181.

BUTLER, T., LEES, L. (2006): Super-gentrification in Barnsbury, London: globalization and gentrifying global elites at the neighborhood level. Transactions of the Institute of British Geographers, 31, No. 4, pp. 467-487.

CAMERON, S. (2003): Gentrification, Housing Redifferentiation and Urban Regeneration: "Going for Growth" in Newcastle upon Tyne. Urban Studies, 40, No. 12, pp. 2367-2382.

CHELCEA, L. (2006): Marginal groups in Central Places: Gentrification, Property Rights and Post-Socialist Primitive Accumulation (Bucharest, Romania). In: Enyédi, G., Kovács, Z. (eds.): Social Changes and Social Sustainability in Historical Urban Centres: The Case of Central Europe. Centre for Regional Studies of Hungarian Academy of Science, Pécs, pp. 107-126.

COOK, A. (2010): The expatriate real estate complex: Creative destruction and the production of luxury in post-socialist Prague. International Journal of Urban and Regional Research, 34, No. 3, pp. 611-628.

DAVIDSON, M. (2007): Gentrification as a global habitat: a process of class formation or corporate creation? Transactions of the Institute of British Geographers, 32, No. 4, pp. 490-506.

DAVIDSON, M., LEES, L. (2005): New-build "gentrification" and London's riverside renaissance. Environment and Planning A, 37, No. 7, pp. 1165-1190.

DAVIDSON, M., LEES, L. (2010): New-build gentrification: its histories, trajectories, and critical geographies, Population, Space and Place, 16, pp. 394-411.

DOUCET, B.M., van KEMPEN, R., van WEESEP, J. (2011): "We're a rich city with poor people": municipal strategies of new-build gentrification in Rotterdam and Glasgow. Environment and Planning A, No. 43, pp. 1438-1454.

ENYÉDI, G., KOVÁCS, Z. (eds.): Social Changes and Social Sustainability in Historical Urban Centres: The Case of Central Europe, Pécs: Centre for Regional Studies of Hungarian Academy of Science, $295 \mathrm{pp}$.

FELDMAN, M. (2000): Waterfront Revitalization and Local Governance in Tallinn, Estonia. Europe-Asia Studies, 52, No. 5, pp. 829-850.

GENTILE, M., SALUKVADZE, J., GOGISHVILI, D. (2015): Newbuild gentrification, teleurbanization and urban growth: placing the cities of the post-Communist South in the gentrification debate. Geografie, 120, No. 2, pp. 134-163.

GERMAIN, A., ROSE, D. (2000): Montreal: The Quest for a Metropolis. John Wiley and Sons, Chichester, 306 pp.

GLASS, R. (1964): Introduction: aspects of change. In: London: Aspects of Change. Centre for Urban Studies, McGibbon and Kee, pp. XVIII-XIX.

GRABKOWSKA, M. (2012): Regeneration of the Post-Socialist Inner-City: Social Change and Bottom-up Transformation in Gdańsk. Pracownia, Gdańsk, 171 pp.

HAMILTON, F.E.I., ANDREWS, K., PICHLER-MILANOVIĆ, N., eds. (2005): Transformation of Cities in Central and Eastern Europe. United Nations University Press, Tokyo, $494 \mathrm{pp}$.

HAMNETT, C. (2003): Gentrification and the middle class remaking of inner London, 1961-2001. Urban Studies, 40, pp. 2401-2426.

HAASE, A., HAASE, D., KABISCH, S., et al. (2005): Monitoring of reurbanisation: conceptual approach and a set of core indicators from a multidisciplinary perspective. Work Package No. 8, Final Report, Re Urban Mobil, Leipzig, 60 pp.

HAASE, A., STEINFÜHRER, A., KABISCH, S., GROSSMANN, K., HALL, R. (eds.) (2012): Residential Change and Demographic Challenge. The Inner City of East Central Europe in the $21^{\text {st }}$ Century. Ashgate, London, $376 \mathrm{pp}$.

HE, S. (2008): New-build gentrification in Central Shanghai: demographic changes and socioeconomic implications. Population, Space and Place, 16, No. 5, pp. 345-361.

HEGEDÜS, J., TOSICS, I. (1991): Gentrification in Eastern Europe: The case of Budapest. In: van Weesep J., Musterd S. (eds.): Urban Housing for the Better-Off: Gentrification in Europe. Stedelijke Netwerken, Utrecht, pp. 124-136.

HELBRECHT, I., BEHRING, K. (2002): Wohneigentum in Europa. Wüstenrot Stiftung. Ludwigsburg, $207 \mathrm{pp}$. 
HERFERT, G. (2002): Disurbanisierung und Reurbanisierung: Polarisierte Raumentwicklung in der ostdeutschen Schrumpfungslandschaft. Raumforschung und Raumordnung, 60 , No. 5/6, pp. 334-334.

HOLM, A. (2010): Townhouses, Urban Village, Car Loft. Berliner Luxuswohnanlagen als "dritte Welle" der Gentrification. Geographische Zeitschrift, 98, No. 2, pp. 100-115.

KABISCH, N., HAASE, D., HAASE, A. (2010): Evolving reurbanisation? Spatio-temporal dynamics as exemplified by the east German city of Leipzig. Urban Studies, 47, No. 5, pp. 967-990.

KACZMAREK, S., MARCINCZAK, S. (2013): Blessing in disguise. Urban regeneration in Poland in a neoliberal milieu. In: Leary M. E., McCarthy J. (eds.): The Routledge Companion to Urban Regeneration. Blackwell, London and New York, pp. 98-106.

KISS, E. (2002): Restructuring in the industrial areas of Budapest in the period of transition. Urban Studies, 39, No. 1, pp. 69-84.

KOVÁCS, Z. (1998): Ghettoisation or Gentrification? Post-socialist Scenarios for Budapest. Netherlands Journal of Housing and the Built Environment, 13, No. 1, pp. 63-81.

KOVÁCS, Z., WIESSNER, R., ZISCHNER, R. (2012): Urban Renewal in the Inner City of Budapest: Gentrification from a Post-socialist Perspective. Urban Studies, 50, No. 1, pp. 22-38.

KSIĄŻCZYK, J. (2012): Analiza rynku nieruchomości miasta Łodzi. Instytut Ekonomiczny NBP: Warszawa, $150 \mathrm{pp}$.

LAMBERT, C., BODDY, M. (2002): Transforming the City: Post-Recession Gentrification and Re-Urbanisation. CNR-Paper 6, pp. 1-26.

LEES, L. (2003): Super-Gentrification: The Case of Brooklyn Heights, New York City. Urban Studies, 40, No. 12, pp. 2487-2509.

LEES, L., SLATER, T., WYLY, E. (2008): Gentrification. Routledge, New York, 316 pp.

LÜTZELER, R. (2008): Population Increase and "New-Build Gentrification" in Central Tōkyō. Erdkunde, 62, No. 4, pp. 287-299.

MARQUARDT, N., FÜLLER, H., GLASZE, G., PÜTZ, R. (2013): Shaping the Urban Renaissance: New-build Luxury Developments in Berlin. Urban Studies, 50, No. 8, pp. 1540-1556.

MARCIŃCZAK, S., SAGAN, I. (2011): The Socio-Spatial Restructuring of Łódź, Poland. Urban Studies, 48, No. 9, pp. 1789-1809.

MARCIŃCZAK, S., MUSTERD, S., STEPNIAK, M. (2012): Where the grass is greener: social segregation in three major Polish cities at the beginning of the $21^{\text {st }}$ century. European Urban and Regional Studies, 19, No. 4, pp. 383-403.

MARCINCZAK, S., GENTILE, M., STEPNIAK, M. (2013): Paradoxes of (post)socialist segregation: Metropolitan sociospatial divisions under socialism and after in Poland. Urban Geography 34, No. 3, pp. 327-52.

MOSZYŃSKA A., MOSZYŃSKI M. (2012): Reprywatyzacja a konflikt interesów ekonomicznych jednostek i państwa - Polska na tle pozostałych krajów transformacji. Ekonomia i Prawo, 8, No. 1, pp. 119-136.

MURZYN-KURPISZ, M. (2013): Cultural quarters as a means of enhancing the creative capacity of Polish cities? Some evidence from Cracow. Quaestones Geographicae, 4, No. 31, pp. 63-76.

NAGY, E., TIMAR, J. (2012): Urban Restructuring in the Grip of Capital and Politics: Gentrification in East-Central Europe. In: Csapo, T., Balogh, A. (eds.): Development of the Settlement Network in the Central European Countries: Past, Present, and Future. Springer: Heidelberg, London, New York, pp. 121-135.

RÉRAT, P., SÖDERSTRÖM, O., PIGUET, E., BESSON, R. (2009): From urban wastelands to new-build gentrification: The case of Swiss cities. Population, Space and Place, 16, pp. 429-442.

ROSE, D. (2002): Gentrification through “infill-tration"? New condo owners' relationships to neighbourhood in a gentrifying economy. Paper presented to the Annual Meeting of the Association of American Geographers, 19-23 March, Los Angeles.

Raport o sytuacji na rynku nieruchomości mieszkaniowych i komercyjnych w Polsce w 2011 r. Instytut Ekonomiczny NBP: Warszawa. 
RINK, D. (2012): Gentrification in einer armen Stadt? Zur Diskussion in Leipzig. Unpublished paper.

ROY, F. (2008): Mortgage Markets in Central and Eastern Europe - A Review of Past Experiences and Future Perspectives. European Journal of Housing Policy, 8, No. 2, pp. 133-160.

SCHNEIDER, A. (2012): Gehobener Wohnungsmarkt in Leipzig. Recherche im Auftrag des Helmholtz-Zentrums für Umweltforschung (UFZ), Department Stadt- und Umweltsoziologie (unter Leitung von Prof. Dr. Dieter Rink), Leipzig, 21 pp.

SCOTT, J.W., KUHN, M. (2012): Urban change and urban development strategies in Central East Europe: a selective assessment of events since 1989. European Planning Studies, 20, No. 7, pp. 1093-1109.

SHAW, K. (2002): Culture, economics and evolution in gentrification. Just Policy, 28, pp. $42-50$.

SLATER, T. (2009): Missing Marcuse: on gentrification and displacement. City, 13, No. 2-3, pp. 293-311.

SMITH, N. (1996): The New Urban Frontier. Gentrification as the revanchist city. Routledge, London, New York, 288 pp.

SMITH, N. (2002): New globalism, new urbanism: gentrification as global urban strategy. Antipode, 34, No. 3, pp. 427-450.

Stadt Leipzig (2009): Kleinräumiges Monitoring der Stadt Leipzig. Monitoringbericht 2009. Leipzig, Dezernat für Stadtentwicklung und Bau, 64 pp.

SÝKORA, L. (2005): Gentrification in post-communist cities. In: Atkinson, R., Bridge, G. (eds.): Gentrification in Global Context: The New Urban Colonialism. Routledge, London, pp. 90-105.

TEMELOVÁ, J. (2007): Flagship developments and the physical upgrading of the postsocialist inner city: The Golden Angel project in Prague. Geografiska Annaler, 89B, No. 2, pp. $169-181$.

VISSER, G., KOTZE, N. (2008): The State and New-build Gentrification in Central Cape Town, South Africa. Urban Studies, 45, No. 12, pp. 2565-2593.

WARDE, A. (1991): Gentrification as consumption: issues of class and gender. Environment and Planning D, Society and Space, No. 9, pp. 223-232.

WYLY, E., HAMMEL, D. (1999): Islands of decay in seas of renewal: Housing policy and the resurgence of gentrification. Housing Policy Debate, 10, No. 4, pp. 711-771.

\section{Shrnutí}

\section{GENTRIFIKACE FORMOU NOVÉ VÝSTAVBY V POST-SOCIALISTICKÉM MĚSTĚ: ŁÓDŹ A LIPSKO DVĚ DESETILETÍ PO SOCIALISMU}

Cílem této studie je ilustrovat tempo, strukturu a lokální projevy gentrifikace formou nové výstavby v polské Lodži a v německém Lipsku (v bývalé NDR), a také zpo̊sob, jakým promlouvá do socio-prostorového uspořádání krajiny vnitřních měst. Tím chceme nabídnout srovnání procesů gentrifikace formou nové výstavby, jakožto fenoménu kladoucímu důraz na vliv nových stavebních projektů na zlepšování sociální struktury v post-socialistickém prostředí s př́íklady známými ze „západních“ měst. Z aspektů gentrifikace formou nové výstavby, které jsou popsány v početné existující literatuře, jsme si pro bližší zkoumání vybrali ty následující: (1) ekonomická dimenze gentrifikace formou nové výstavby, (2) geografická dimenze procesu a (3) sociální profil nositelů gentrifikace. Jedním z důležitých poznatků naší studie se ukázal být význam rychlosti post-socialistické transformace a institucionálních rámců na tempo a rozsah gentrifikace formou nové výstavby. Např́iklad velká města bývalé NDR podstupovala transformaci mnohem rychleji než jejich příbuzná (a srovnatelná) města ve střední a východní Evropě. Zatímco v Lipsku nabrala obnova historického jádra spád již v polovině devadesátých let, v Lodži začala obdobná regenerace až o dekádu později, když se město více napojilo na globální toky kapitálu a služeb. I přes tuto časovou propast se zdá, že výsledky šetření v Lodži i v Lipsku poukazují na to, že „klasická“ gentrifikace i gentrifikace formou nové výstavby působí na socio-prostorovou strukturu vnitřních měst současně. 
Pokud jde o dopady gentrifikace formou nové výstavby na socio-prostorovou skladbu vnitroměstských čtvrtí, tak důkazy nasvědčují, že spíše konzervuje a posiluje již existující vysoký status vybraných lokalit, než že by přispívala k jejich „supergentrifikaci“, popřípadě (což je relativně časté) přispívá k většímu sociálnímu mísení. Tyto dopady ovšem nejsou univerzální. Sociální mísení způsobené variantami gentrifikace formou nové výstavby v Lodži se může velmi lišit od zdravého promíchání socioekonomických skupin jaké lze identifikovat v lépe prosperujících post-socialistických městech. Selektivní zlepšování sociální struktury může naopak vést ke kombinované sociální polarizaci, což v praxi znamená, že uživatelé nových luxusních obydlí bydlí jenom pár kroků od domácností nízkopř́ijmových skupin. V Lipsku je socio-prostorový kontext, ve kterém dochází $\mathrm{k}$ výstavbě nových luxusních domů poněkud odlišný než v Polsku. V tomto případě se jedná primárně o „obyčejné“ čtvrti s relativně dobrým obytným prostředím a obyvatelstvem patřícím vesměs ke střední třídě. Jinými slovy, gentrifikace formou nové výstavby se často nachází v atraktivních lokalitách - na nábřeží či v těsné blízkosti městských parků a lesů. Geografická distribuce luxusních stavebních projektů v Lipsku se zpravidla neshoduje se vzorcem lokalit zažívajících průlomovou gentrifikaci a území, kde gentrifikace probíhá, nebývají primárním cílem pro nové stavební projekty. Vzhledem $\mathrm{k}$ tomu, že nové projekty konstrukce obytných budov v centrálních lokalitách bývají dražší než jinde (některé se řadí přímo k těm nejdražším ve městě) a že průměrná mzda postačí na zakoupení o něco více než poloviny čtverečního metru v průměrném bytě v centru města, dá se očekávat, že případní uživatelé se budou rekrutovat zejména mezi vyšší střední třídou a místními socio-ekonomickými elitami. Protože jsou obě studovaná města stále více vystavena globálním tokům investic a pracovní síly, část nových obytných jednotek, zejména luxusnějších bytů, je obsazena rezidentními občany ze zemí západní Evropy. $\mathrm{S}$ ohledem na mezinárodní akademickou debatu o funkci gentrifikace formou nové výstavby je potřeba uvést, že Lodž i Lipsko představují velice specifický modus tohoto procesu. I přes nepopiratelné podobnosti s prostorovým vzorcem identifikovaným předchozími studiemi na případech „západních“ měst, kde se nové obytné projekty soustředí do centrálních oblastí města, je potřeba vést $\mathrm{v}$ patrnosti, že gentrifikace formou nové výstavby identifikovaná v námi analyzovaných městech poukazuje na odlišné ekonomické kořeny i společenské dopady. V obou případech, přes jejich vzájemné odlišnosti, působí gentrifikace formou nové výstavby ekonomicky nezávisle na klasických formách gentrifikace a jejich dynamikách. Jinými slovy, na rozdíl od „západních“ měst není gentrifikace formou nové výstavby ve střední a východní Evropě vázána na třetí vlnu gentrifikace, nebot’ gentrifikační vlny se v post-socialistických městech překrývají a slučují. Tak jako na „západě“, i ve městech střední a východní Evropy zahrnuje gentrifikace formou nové výstavby výstavbu více i méně luxusních obytných budov a zřetelně přispívá ke zlepšování sociální struktury obyvatel. V Lodži nejsou stavební aktivity $\mathrm{v}$ historickém centru omezené jen na nejvyšší tržní segment a vycházejí zejména z rozdílu mezi skutečným a potenciálním výnosem z nemovitosti na zastavěných i prázdných pozemcích s jasnou vlastnickou strukturou.

Za podmínek uvolněného trhu s nemovitostmi, tak jako v případě Lipska, ale mohou být exkluzivní bytové projekty jedinou příležitostí jak zvýšit hodnotu nájmu nad její průměrnou výši (v kontextu celého města).

Závěrem lze ještě konstatovat, že vzhledem k pomalé gentrifikaci historické domovní zástavby ve městech střední a východní Evropy nabízí gentrifikace formou nové výstavby, včetně méně ambiciózních projektů zaměřených na střední třídu, na post-socialistických trzích s bydlením první reálnou možnost jak využít rozdílu nájemní hodnoty a v budoucnu by se tak mohla stát předmětem tržních strategií.

Obr. 1 -Gentrifikace formou nové býstavby a socio-prostorové fragmentace v historickém jádru města Lodže.

Obr. 2 -Gentrifikace formou nové výstavby a okolní socioekonomická polarizace.

Obr. 3 - Prostorový model nových stavebních činností v Lipsku (2000-2011). 
Authors'affiliation: A. Holm: Humboldt-Universität Berlin, Germany. S. Marcińczak, A. Ogrodowczyk: University of Łódź, Poland; e-mail: szymon.marcinczak@geography.umu.se.

Initial submission, 2 July 2014; final acceptance 18 April 2015.

\section{Please cite this article as:}

HOLM, A., MARCIŃCZAK, S., OGRODOWCZYK, A. (2015): New-build gentrification in the post-socialist city: Łódź and Leipzig two decades after socialism. Geografie, 120, No. 2, pp. 164-187. 